\title{
Desenvolvimento de conteúdos educacionais: dimensões sobre conceitos, gestão e produção
}

DOI: https://doi.org/10.1590/1809-58442020112

\author{
Angela Tamires Nascimento Alexandre ${ }^{1}$ \\ https://orcid.org/0000-0001-9719-542X
}

${ }^{1}$ (Universidade Federal do Pará, Núcleo de Inovação e Tecnologias Aplicadas a Ensino e Extensão, Programa de Pós-Graduação Criatividade e Inovação em Metodologias de Ensino Superior. Belém - PA, Brasil).

FILATRO, A.; CAIRO, S. Produção de conteúdos educacionais: design instrucional, tecnologia, gestão, educação e comunicação. São Paulo: Saraiva, 2017.

O livro "Produção de Conteúdos Educacionais: design instrucional, tecnologia, gestão, educação e comunicação”, desenvolvido por Andrea Filatro com a colaboração de Sabrina Cairo, aborda como tema central a produção de conteúdos voltados para o ensino. O livro é dividido em três partes: a primeira apresenta as dimensões conceituais que alicerçam a produção de conteúdos educacionais; a segunda parte trata da gestão de projetos, apresentando as etapas e de que forma o planejamento é seguido até a concretização do

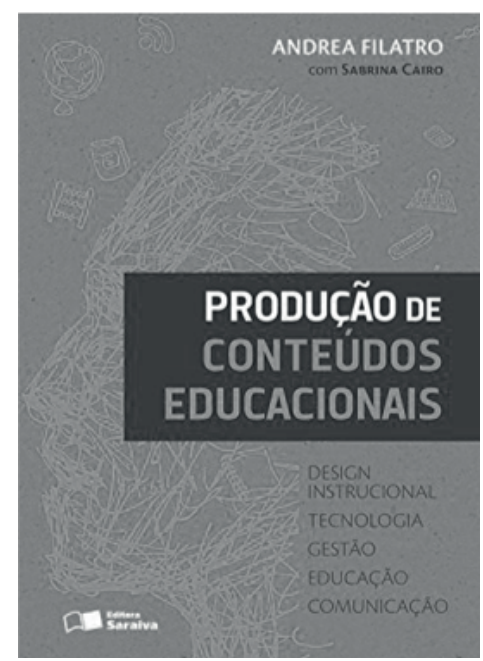
produto ou processo educacional; e a terceira parte apresenta as atividades de produção inseridas no projeto que resultará em um conteúdo educacional.

A primeira parte do livro se divide em cinco capítulos. O primeiro, denominado “Dimensão Tecnocientífica”, faz um apanhado sobre a natureza dos conteúdos educacionais e apresenta formas de organização curricular de acordo com dimensões sobre os quais o aprendizado é pautado, perpassando pelos conteúdos, competências, habilidades e ações desenvolvidas no decorrer do processo formativo. As autoras trabalham na perspectiva da taxonomia afetiva de Bloom e dos questionamentos de Tyler (1974), que apresentam questões norteadoras de currículos, abarcando propósitos, experiências e objetivos educacionais. A tipologia dos conteúdos educacionais propostas por Zabala (1998) também é discutida, considerando o termo "conteúdo educacional" como tudo aquilo que se deve aprender, considerando aspectos conceituais, cognitivos e relacionais.

No capítulo dois, “Dimensão Pedagógica”, são discutidas as principais correntes teóricas que explicam o processo de aprendizado. Ao conhecer o contexto e as necessidades 
dos aprendizes, é possível pautar o conteúdo educacional em uma perspectiva que auxilie o aluno a desenvolver competências e habilidades contextualizadas às suas necessidades, visando o seu desenvolvimento.

No capítulo três, “Dimensão Comunicacional”, as autoras discutem a perspectiva de interlocução, na qual emissor e receptor configuram-se como coautores da mensagem. Pensando nisso, as autoras discutem que o especialista que planeja e constrói o conteúdo educacional deve construir um quadro mental, pensando a quem o produto se destina. Elas orientam como construir materiais educacionais capazes de promover a aproximação, a motivação e o prazer intelectual entre alunos e professores.

No capítulo quatro, intitulado “Dimensão Tecnológica”, citando Moore e Kearsley (2007), as autoras definem as tecnologias como veículos comunicacionais de mensagens representadas em uma mídia, configurando canais de comunicação. As autoras também abordam os objetos de aprendizagem e os caracterizam como um padrão que permite organizar recursos de aprendizagem isolados em um pacote fechado e autocontínuo por meio de metadados.

O capítulo cinco, “Dimensão Organizacional”, discute a produção de conteúdos educacionais a partir do aspecto sistêmico, que considera o conteúdo educacional como uma coleção de objetos cujas características não podem ser divididas em elementos composicionais. Dessa forma, o projeto ou produto que se está planejando, apesar de suas partes e etapas de desenvolvimento, deve apresentar funcionamento orgânico, com feedback e reatroalimentação, constituindo autorregulação. Para explicar esses aspectos, o capítulo apresenta modelos de produção e de gestão de projetos.

A segunda parte do livro é denominada “Gestão de Produção” e é composta por três capítulos que apresentam planos, etapas e gerência de projetos. O capítulo seis apresenta uma visão geral dos projetos. Segundo Filatro e Cairo (2017), a metodologia de gestão de projetos é necessária para sincronizar e integrar todas as etapas do mesmo. Assim, são apresentados vários modelos utilizados na gestão de projetos e como podem ser geridas as partes de um projeto.

O capítulo sete discute o Design Instrucional, que, segundo as autoras, prescreve como assegurar que as pessoas aprendam em situações específicas. O Design Instrucional tem o papel de identificar um problema ou uma necessidade de aprendizagem para desenhar uma proposta que atenda esse problema ou necessidade, para depois implementar e avaliar a solução. Existem vários modelos de Design Instrucional que seguem as seguintes fases: identificação de uma necessidade, projeção de uma solução (design), desenvolvimento da solução (produção), implementação da solução (aplicação) e avaliação da solução (resultados).

No capítulo oito, as autoras se debruçam sobre o plano do projeto e trabalham o triangulo de prioridades: escopo, custo e tempo. 
A terceira parte do livro, intitulada “Atividades de Produção”, é dividida em quatro capítulos e apresenta aspectos mais práticos da produção de conteúdos educacionais, ao abordar formas de como desenvolver as etapas. No capítulo nove, denominado "Análise Contextual”, as autoras discutem blocos de interesse para a produção, que são: identificação de necessidades de aprendizagem, caracterização do público, levantamento de potencialidades e restrições institucionais. Para análise do contexto ao qual o conteúdo educacional será destinado, as autoras indicam fazer coleta de dados por meio de vários instrumentos como entrevistas, questionários e afins. As autoras apresentam, no capítulo, vários modelos consolidados para trabalhar a motivação com os alunos.

No capítulo 10, as autoras discutem o planejamento educacional. Segundo elas, o planejamento deve prever a apresentação de conteúdos e a proposição das atividades, levando em conta o contexto dos alunos, objetivos de aprendizagem, atividades práticas e afins.

No capítulo 11 as autoras apresentam diversas técnicas e recursos que auxiliam na autoria de conteúdos educacionais o orientam sobre a voz do autor no produto, ineditismo e outros aspectos inerentes a autoria. No capítulo 12, as autoras abordam a produção de roteiros para diferentes tipos de produtos que podem ser voltados para o ensino como vídeos, hipermídias, histórias em quadrinhos, entre outras produções.

Por meio do texto, as autoras apresentam como podem ser construídos produtos e conteúdos educacionais que se preocupem com problemas e possíveis estilos de aprendizado dos estudantes. Assim, é possível que o leitor tenha conhecimento não só das etapas que se seguem ao longo da construção, como também entenda a importância de cada uma delas, para que, desta forma, consiga adotar um planejamento sólido e eficaz caso venha a desenvolver conteúdos educacionais.

\section{Referências}

FILATRO, A; CAIRO, S. Produção de conteúdos educacionais: design instrucional, tecnologia, gestão, educação e comunicação. 1. ed., São Paulo: Saraiva, 2017.

MOORE, M. G.; KEARSLEY, G. Educação a distância: uma visão integrada. São Paulo: Thomson Learning, 2007.

TYLER, R. Princípios básicos de currículo e ensino. Porto Alegre: Globo, 1974.

ZABALA, A. A prática educativa: como ensinar. Porto Alegre: Artes Médicas, 1998. 


\section{Angela Tamires Nascimento Alexandre}

Mestre em Ensino pelo Programa de Pós-Graduação em Criatividade e Inovação em Metodologias de Ensino Superior (PPGCIMES), pela Universidade Federal do Pará (UFPA), 2019. Graduada em Licenciatura Plena em Ciências Naturais com Habilitação em Biologia, pela Universidade do Estado do Pará (UEPA), 2017. Atua como colaboradora do Laboratório de Pesquisa e Experimentação em Multimídia, do Núcleo de Inovação e Tecnologias Aplicadas a Ensino e Extensão (NITAE²-UFPA). E-mail: tamiresalexandre16@gmail.com.

Recebido em: 20.05.2019

Aprovado em: 10.12 .2019 